\title{
The Effect of Talent Management on Organizational Effectiveness in Healthcare Sector
}

\author{
Bader Obeidat ${ }^{1}$, Haneen Yassin ${ }^{1} \&$ Ra'ed Masa'deh ${ }^{2}$ \\ ${ }^{1}$ Department of Business Management, School of Business, The University of Jordan, Amman, Jordan \\ ${ }^{2}$ Department of Management Information Systems, School of Business, The University of Jordan, Amman, \\ Jordan \\ Correspondence: Bader Obeidat, Department of Business Management, School of Business, The University of \\ Jordan, Amman, Jordan. E-mail: b.obeidat@ju.edu.jo
}

Received: May 19, 2018

Accepted: September 20, 2018 Online Published: October 29, 2018

doi:10.5539/mas.v12n11p55

URL: https://doi.org/10.5539/mas.v12n11p55

\begin{abstract}
This study aim is to investigate the direct effect of talent management on organizational effectiveness in the health care sector. The study population consisted of all working employees at all levels, from the medical and the managerial domains with a total of 3512 employees, a quantitative research design and regression analysis were used to a convenience sample on a total of 251 valid returns that were gained in a questionnaire based survey, applied among workers from Joint Commission International (JCI) accredited Jordanian private hospitals. The findings showed that there is a strong positive correlation between the study variables; talent management and organizational effectiveness; talent management with its dimensions; attract talent, maintain talent, and develop talent, have a significant effect on organizational effectiveness. In addition the organizational effectiveness dimensions, namely job satisfaction, and organizational involvement were positively and significantly related to each other. This study implies that Jordanian hospitals should try their best to adopt and facilitate talent management strategies implementation to keep its talented employees in nurture tone and more sustained, which will eventually yield favorable results for those hospitals in regard with its effectiveness.
\end{abstract}

Keywords: talent management, organizational effectiveness, healthcare sector, Jordan

\section{Introduction}

During the past years, organizations competed among each other by achieving and maintaining the highest level of quality, through covering and fulfilling their consumers' needs and wants (Collings and Mellahi, 2009; Obeidat et al., 2017). The concept even later went beyond to exceeding the expectations. However, this trend has shifted as talent management became the new formula to succeed, organizations from all domains and business fields realize how they need to rely on more substantial, perpetual source to grant a certain limit of competency and efficiency. This view is supported by the late king Hussein saying: "Man is our best and most precious asset". In light of this, management of talent and human resource might be more prevailing in the service sector where it indicated significant impact. Meanwhile, the Jordanian health care sector faces some obstacles related to license regulation, rivalry among competitor hospitals, rapid technological and medical advancement, and the troubled political and security conditions in the region, as well as brain drain. These factors place a serious stress over health care providing organizations. One of the challenging yet possible solution to minimize the effect of those problems is to focus on spending the maximum effort and maintaining top performance in order to succeed and increase the hospital's effectiveness; and this relies on the abilities, skills, knowledge, and expertise of the workforce and how to manage and get benefit from these resources (Ministry of Health Annual Report, 2013).

While researches has not been profoundly focused and tested in the Jordanian economy as it should be (El-Tohamy and Al Raoush, 2015). Therefore, it has been advised to re-examine the effect of this variable. Moreover, it has been further noted that the available literature concerning the effect of talent management on organizational effectiveness in health care sector specifically is scarce. The main goal of this study is to examine the effect of talent management on organizational effectiveness. Organizational effectiveness represents the achievement of the organization's predetermined goals and objectives (Amah and Ahiauzu, 2013; Masa'deh et al., 2015). Meantime, talent management provides distinctive strategic opportunities for both; the intended entity and the human resource management field (Schuler et al., 2011). Considering that Jordan's economy relies 
heavily on the service sector with more than $70 \%$ of the recorded firms are service-providing firms (Suifan et al., 2015), the private health care sector was chosen to be examined in this study since Jordan's healthcare system is regarded as one of the best in the region. It has the highest per capita rate of health-related expenditures, after Saudi Arabia and Lebanon. Jordan is also renowned, both regionally and internationally, for its high-quality healthcare services. In 2010, Jordan was ranked as the leading medical tourism destination in the Arab World by the World Bank and fifth globally (Al Azmi et al., 2012; Ministry of Health Annual Report, 2013).

The obtained results of this study can help organizations in several ways; firstly, managers can gain a deep comprehension of the huge importance of talent management, and help them to achieve better talent capturing and nurturing to grant long-term business prosperity for their organizations. Secondly, the results may also help the recruiting instrument of the human resource department. Thirdly, the results might help heighten a solid communication network among the entire working staff, which will ultimately benefit the organizational effectiveness. Lastly, the contribution of this study might approach the managerial aspect within health care filed in regard with talent management. In this study, the choice fell on the accredited private Jordanian hospitals to represent the population due to their eminent weight among the Jordanian healthcare sector. In addition, the private sector hospitals are competing fiercely to be locally and internationally certified in order to improve and maintain their service quality, efficiency and effectiveness of the healthcare work structure, processes, and outputs via assuring the implementation of the set principals and standards by these accrediting bodies. It is worth mentioning that private hospitals sector is witnessing prosper during the past twenty years that the number of private hospitals in Jordan has reached over 60 hospitals all over the kingdom.

This paper is organized as follows: the first section sets the context of the need to study the influence of talent management on the Jordanian health care facilities. The next section examines the research conceptual framework and hypotheses. The next section indicates the research methodology, and the final section provides the results and research conclusions.

\section{Research Framework and Hypotheses}

This research was conducted to study the impact of talent management on organizational effectiveness in the Jordanian healthcare sector, where this sector is highly important and competitive.

\subsection{Operational Definitions}

Dependent, independent and mediating variables of the study are operationalized as follows.

\subsubsection{Talent Management (Independent Variable)}

Talent management refers to the manager or supervisor's ability to define and determine if a certain person practically obtains beyond the average level of skills and requirements that qualifies him or her to perform in the organization. This talent shall be hired and fully used to heighten the overall organizational aptitude. Another operational definition of talent management refers to the human being's ability; which includes dexterity, proficiency, and skillfulness for improvement. Talent management was operationalized using the dimensions of attracting the talent, talent maintenance, and talent development.

The questionnaire used in this study contained 28 items for talent management scale adopted from a study conducted by Nobarieidishe et al. (2014), and this measure relies on three aspects; Attract Talent, Maintain Talent, and Develop Talent.

\subsubsection{Attract Talent}

Talent attraction can be defined as the management ability to capture and assess the potential employee's ability including skills, dexterity, proficiency and willingness for improvement. The study's questionnaire contained a specific set of questions, as the first group of questions, under talent management section (Item no. 1-9), whereas all items are measured using a five-point rating scale, rating from one: "strongly disagree", two: "disagree", three: "moderately agree", four: "agree", to five: "strongly agree".

\subsubsection{Maintain Talent}

The submitted efforts by the organization to retain a very good working ambiance, and founders for open and healthy communication channels with the talented employees, that is reflected in their job satisfaction positively. The study's questionnaire contained a specific set of questions, as the second group of questions, under talent management section (Item no. 10-15), and all items are measured using a five-point rating scale, rating from one: "strongly disagree", two: "disagree", three: "moderately agree", four: "agree", to five: "strongly agree". 


\subsubsection{Develop Talent}

This concept refers to the organizational strong commitment to nurturing the talents through adapting strategies to make their human resources commit to training courses, learning campuses, paid scholarships, workshops and picking out the latest technologies. The study's questionnaire contained a specific set of questions, as the second group of questions, under talent management section (Item no. 16-25), those items are measured using a five-point rating scale, rating from one: "strongly disagree", two: "disagree", three: "moderately agree", four: "agree", to five: "strongly agree".

\subsubsection{Organizational Effectiveness (Dependent Variable)}

Organizational effectiveness refers to the organization's success in achieving its pre-stated objectives via formulating its current resources totally, which could be reflected on the employee's degree of satisfaction with their current job positions, and the degree of their involvement with the organizations. Organizational effectiveness is operationalized into two dimensions; the first is the extent of an employee's satisfaction towards his or her job. Job satisfaction can be reflected in having a good connection and communication with his or her supervisor, a good income, ability to perform the job's tasks effectively. The second dimension is related to the extent of involvement with the organization that the employee enjoys; on an emotional, continuance, and normative base.

The applied questionnaire contained 42 items for organizational effectiveness scale, which were adopted from a study conducted by Allen and Meyer (1990). This measure relied on two aspects; Job Satisfaction, and organizational effectiveness.

\subsubsection{Job Satisfaction}

Job satisfaction refers to the degree to which the employee is content with his/ her job nature, and to what extent he/she is compatible with the provided awards such as; the amount of payment, insurance coverage, travel, scholarships. It has been mentioned in the applied questionnaire, composed of four more section; First: Professional-Manager Interaction (Item no. 26-32), Second: Pay (Item no. 33-37), Third: Supervisor-Supervisee Interaction (Item no. 38-42), and Four: Job Requirements (Item no. 43-45). And all items were measured using a five-point rating scale, rating from one: "Strongly disagree", two: "Disagree", three: "Moderately agree", four: "Agree", to five: "Strongly agree".

\subsubsection{Organizational Involvement}

Organizational involvement can be defined as the degree of which the organization creates a fertility environment that enhances the employees to make a considerable participation of the decisions processes and actions which impact their work. Overall, this will affect the degree of the employee's commitment and unity with the organization. This aspect exist in the applied questionnaire divided into three sections: First, Affective (Item no. 46-53), second Continuance (Item no. 54-60), and third Normative (Item no. 61-68). Whereas all items were measured using a five-point rating scale, rating from one: "Strongly disagree", two: "Disagree", three: "Moderately agree", four: "Agree", to five: "Strongly agree". Research theoretical model is illustrated in figure (1) which clarifies the relationship between study variables.

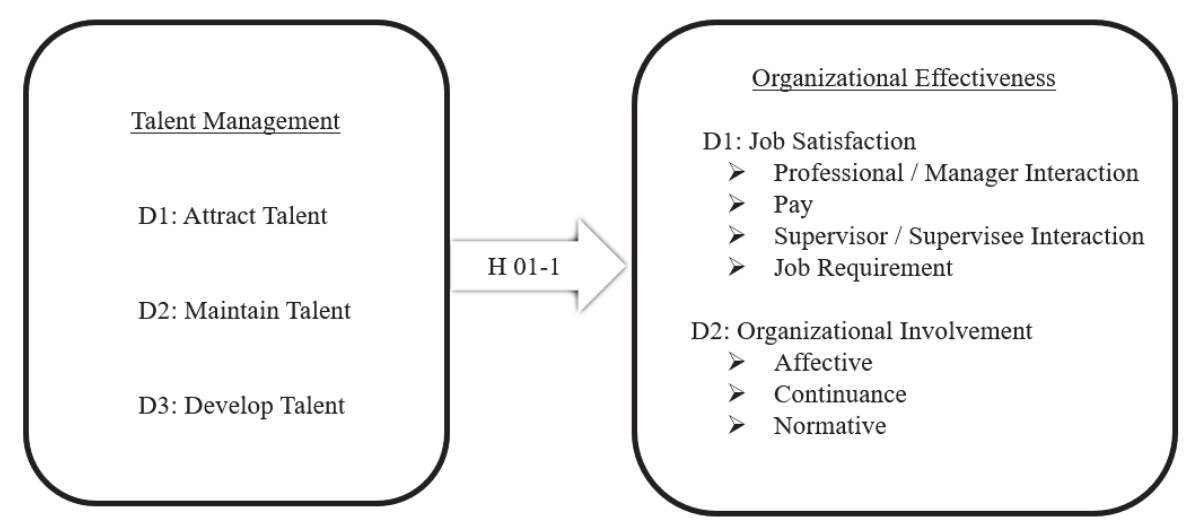

Figure 1. Schematic diagram for the study variables and their connections based on a study conducted by Nobarieidishe et al. (2014), and a study conducted by An et al. (2011)

The following hypotheses were developed to test the effect of talent management on organizational 
effectiveness:

\section{The Main Hypothesis}

H01: There is no statistically significant effect (at the level $\alpha \leq 0.05$ ) of talent management on organizational effectiveness at the Jordanian JCI accredited private hospitals.

The Sub-Hypotheses

H01.1: There is no statistically significant effect (at the level $\alpha \leq 0.05$ ) of attracting talents in health care sector.

H01.2: There is no statistically significant effect (at the level $\alpha \leq 0.05$ ) of maintaining the talents in health care sector.

H01.3: There is no statistically significant effect (at the level $\alpha \leq 0.05$ ) of developing the talents in health care sector.

\subsection{Population and Sample of the Study}

To achieve the purpose of this study of examining the effect of talent management on organizational effectiveness; the relevant population included employees from five Jordanian, Joint Commission International accredited, private hospitals. The hospitals selected were: The Specialty Hospital, Jordan Hospital, Al Essra Hospital, Al Khalidi Hospital, and Al Istishari Hospital. There are many reasons for carrying out sampling from these five hospitals. First of all, these five hospitals constitutes a considerable proportion in terms of numbers of beds for the private health care sector in Jordan (with 780 bed), and number of employees (with 3512 employee) which provide a variety of health care services and employ a relatively large number of health care employees, who are generally are employed on long term contracts. Furthermore, those five hospitals considered as elite organizations of providing health care services in terms of accreditation, all of them obtained JCI accreditation and other certificates, thus, there is a quiet level of awareness about strategies and polices regarding talent management and HRM toward their employees in general.

The human resource departments was contacted in each of the five hospitals in order to assist in data collection by declaring some needed information about their willingness to participate in this study, JCI accreditation validation, as well as information about their working staff. The population consisted of all working employees at all levels, from the medical and the managerial domains. After viewing each of which the latest annual report, it turns out that the total number of employees working in the combined five hospitals at the end of 2016 was 3512 worker. The next table gives a detailed specification of the number of employees at each of the involved hospitals.

Table 1. The Five JCI Accredited Hospitals in Jordan Appropriate Sample Size

\begin{tabular}{|c|c|c|}
\hline Hospital Name & Number of & Amount estimated of Sample \\
\hline The Specialty & 845 & 83.49 \\
\hline Jordan & 761 & 75.19 \\
\hline Al Essra & 736 & 72.72 \\
\hline Al Khalidi & 700 & 69.16 \\
\hline Al Istishari & 470 & 46.44 \\
\hline Total & 3512 & 347 \\
\hline
\end{tabular}

Due to some constraints of time, cost, and lack of cooperation, a convenient sample was chosen, which is a non-probability sample, including randomly chosen entities that were the easiest to obtain for the purpose of this study. Due to the fact that the population equals (3512) employee, the appropriate suggested sample size is (347) employee.

\subsection{Data Collection Methods}

A secondary data collection in this research is carried out through published studies, articles, and reports by the Ministry of Health, Civil Service Bureau, Private Hospitals Association, journal articles, and other research papers about the subject needed to build the existing research on. Also, primary data are gathered through a personally administrative questionnaire. The questionnaire is divided into three parts, starting with a demographic related data section, then moving to the other two sections, titled; talent management (adopted from a study conducted by Nobarieidishe et al., 2014), and organizational effectiveness (adopted from a study conducted by Allen and Meyer,1990). 


\subsection{Validity and Reliability}

Validity is related to the meaningfulness of the research components (Drost, 2011). Another definition of the validity indicates that it measures the used instrument goodness and suitability in measuring in the study's variables (Sekaran and Boujie, 2012). Whereas the reliability concerned about whether the measurement tool proves on the steadiness and the constancy of the measured concepts, it is also considered as the instrument mirror that reflects its precision and thoroughness (Drost, 2011).

\subsubsection{Face Validity}

Face validity indicates whether the used measurement instrument does actually measure what it is intended for (Oppenheim, 1992). In order to assert the face validity, minor amendments due to translation errors were done before the measurement instrument was piloted on a sample of 15 Accredited Jordanian private hospitals employees, and the feedback was sought as to its face validity. Thus, the results of the pilot study were initially valid and acceptable to proceed with distributing the questionnaire for the entire determined sample.

\subsubsection{Construct Validity}

Construct validity refers to whether the test measures the under consideration construct (Messick, 1998). There are various procedures to be followed in order to figure out if the study measurement instrument, the study questions, and the study framework are valid and appropriate for the study analysis. The used test in this study is the Confirmatory factor analysis (CFA). According to Hair et al. (2010), the confirmatory factor analysis assures on the validity of the study clauses and the contextual dimensions, as long as the standard regression significant values of the latent variables are greater than (0.4). The constructed model could be divided into two types of variables, the latent variables, and the exogenous variables, which describes the suggested dimensions that must be tested. Moreover, a set of arrows pointed to the other type of variables, are the implicit variables which indicate sentences with their dimensions. The following chart shows the construct validity of talent management:

Standardized Regression Weights:

\begin{tabular}{llll}
\hline & & & Estimate \\
\hline Q9 & $<---$ & MT & .495 \\
Q8 & $<--$ & MT & .613 \\
Q7 & $<--$ & MT & .516 \\
Q6 & $<---$ & MT & .474 \\
Q5 & $<--$ & MT & .576 \\
Q4 & $<--$ & MT & .333 \\
Q3 & $<---$ & MT & .697 \\
Q2 & $<--$ & MT & .847 \\
Q1 & $<--$ & MT & .803 \\
Q15 & $<---$ & MM & .739 \\
Q14 & $<--$ & MM & .768 \\
Q13 & $<---$ & MM & .663 \\
Q12 & $<---$ & MM & .519 \\
Q11 & $<--$ & MM & .722 \\
Q10 & $<---$ & MM & .714 \\
Q25 & $<---$ & DM & .742 \\
Q24 & $<--$ & DM & .663 \\
Q23 & $<---$ & DM & .788 \\
Q22 & $<---$ & DM & .818 \\
Q21 & $<--$ & DM & .834 \\
Q20 & $<---$ & DM & .857 \\
Q19 & $<---$ & DM & .770 \\
Q18 & $<---$ & DM & .773 \\
Q17 & $<---$ & DM & .758 \\
Q16 & $<---$ & DM & .764 \\
\hline
\end{tabular}

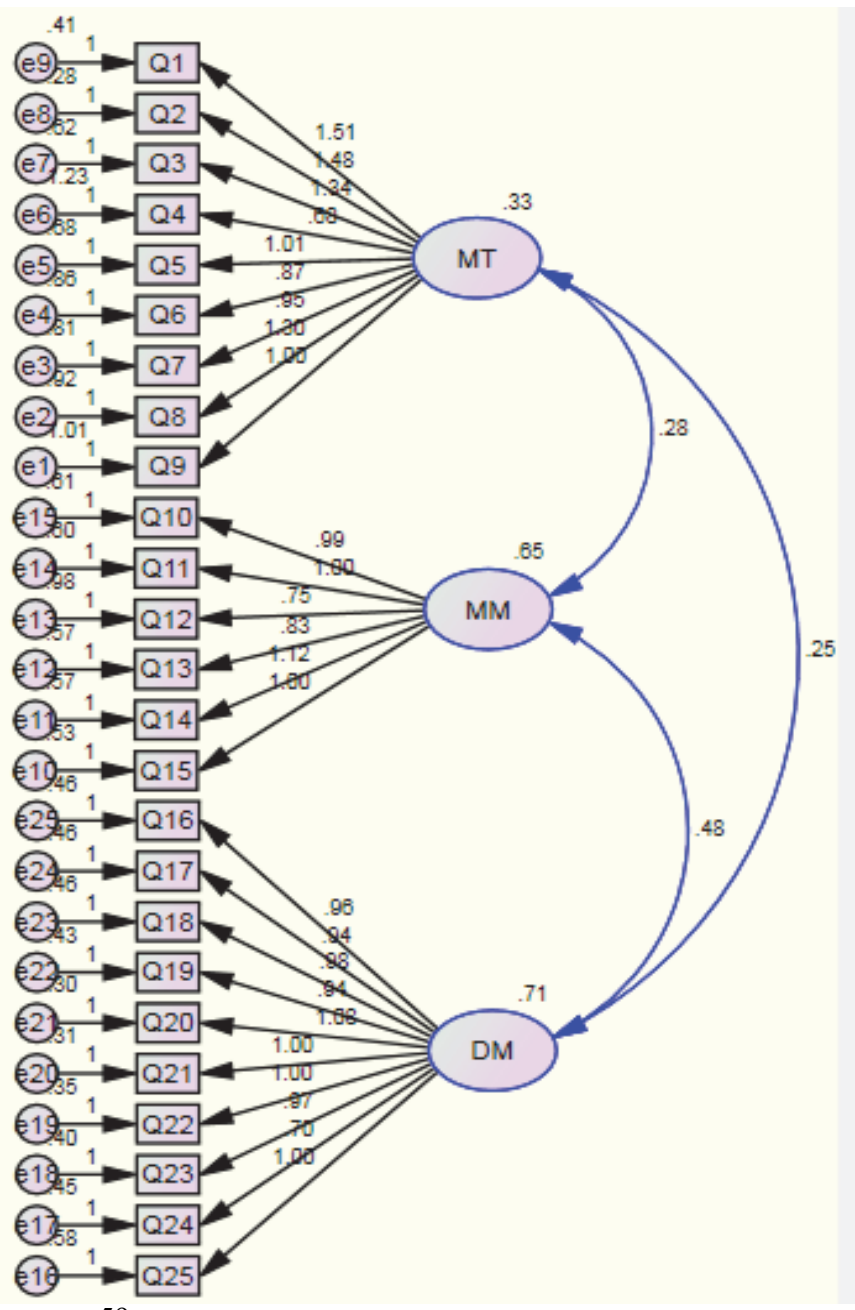




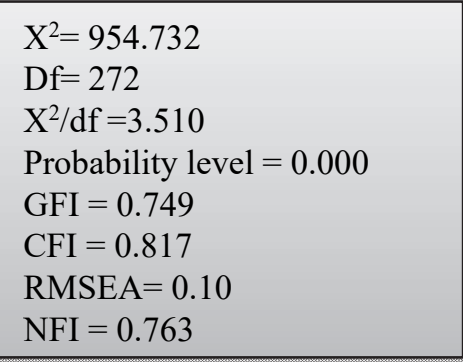

Figure 2 . The construct validity of talent management

The results above show that the value of $\mathrm{Chi}^{2}$ is (954.732) and it is significant at $(\alpha \leq 0.05)$. Also, the Minimum Discrepancy value $\left(\mathrm{Ch}^{2} / \mathrm{DF}\right)$ is (3.510) which specified that the harmonization level is good; where (Arbuckle, 2008) stated that the harmonization level range 1 to 5. The Goodness of Fit Index (GFI) which represent the harmonization of quality is (0.749) and this value is close to one (Full compatibility). The value of Comparative Fit Index (CFI) is (0.817) and it is also close to one. Furthermore, the result above shows that the value of Root Mean Square Error of Approximation (RMSEA) is (0.10) is close to zero. Also, the value of Normed Fit Index (NFI) is (0.763) and it is close to one. Additionally, the table above shows that the values of Standardized Regression Weight for Organization Performance are higher than (0.4) (Hair et al., 2010: 116).

\begin{tabular}{|l|}
\hline$X^{2}=519.529$ \\
$\mathrm{Df}=164$ \\
$\mathrm{X}^{2} / \mathrm{df}=3.167$ \\
Probability level $=0.000$ \\
$\mathrm{GFI}=0.794$ \\
$\mathrm{CFI}=0.829$ \\
$\mathrm{RMSEA}=0.093$ \\
$\mathrm{NFI}=0.771$ \\
\hline
\end{tabular}

Standardize Regression Weights:

\begin{tabular}{llll}
\hline & & & Estimate \\
\hline Q32 & $<---$ & F1 & .784 \\
Q31 & $<--$ & F1 & .786 \\
Q30 & $<---$ & F1 & .807 \\
Q29 & $<---$ & F1 & .665 \\
Q28 & $<---$ & F1 & .740 \\
Q27 & $<---$ & F1 & .574 \\
Q26 & $<--$ & F1 & .737 \\
Q37 & $<---$ & F2 & .460 \\
Q36 & $<---$ & F2 & .646 \\
Q35 & $<---$ & F2 & .467 \\
Q34 & $<---$ & F2 & .636 \\
Q33 & $<---$ & F2 & .189 \\
Q42 & $<---$ & F3 & .613 \\
Q41 & $<---$ & F3 & .658 \\
Q40 & $<--$ & F3 & .839 \\
Q39 & $<---$ & F3 & .732 \\
Q38 & $<---$ & F3 & .783 \\
Q45 & $<---$ & F4 & .658 \\
Q44 & $<---$ & F4 & .387 \\
Q43 & $<---$ & F4 & .810 \\
\hline & & & \\
\hline
\end{tabular}

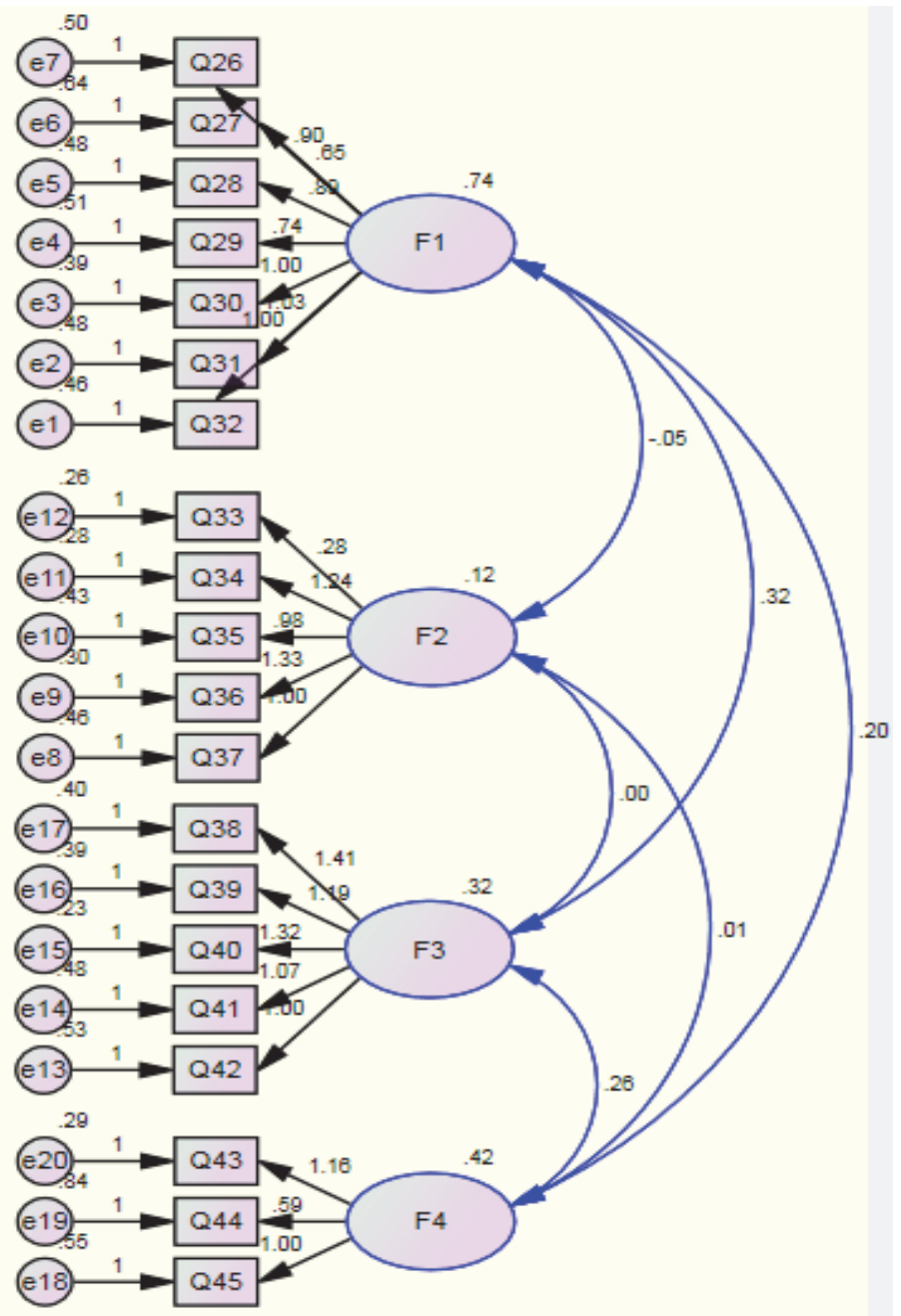

Figure 3. The construct validity of job satisfaction

The results above show that the value of $\mathrm{Chi}^{2}$ is (519.529) and it is significant at $(\alpha \leq 0.05)$. Also, the Minimum 
Discrepancy value $\left(\mathrm{Ch}^{2} / \mathrm{DF}\right)$ is (3.167) which specified that the harmonization level is good; where (Arbuckle, 2008) stated that the harmonization level range 1 to 5. The Goodness of Fit Index (GFI) which represent the harmonization of quality is (0.794) and this value is close to one (Full compatibility). The value of Comparative Fit Index (CFI) is (0.829) and it is also close to one. Furthermore, the result above shows that the value of Root Mean Square Error of Approximation (RMSEA) is (0.093) is close to zero. Also, the value of Normed Fit Index (NFI) is (0.771) and it is close to one. Additionally, the table above shows that the values of Standardized Regression Weight for Organization Performance are higher than (0.4) (Hair et al., 2010, p. 116).

\begin{tabular}{|l|}
$\mathrm{X}^{2}=1085.111$ \\
$\mathrm{Df}=227$ \\
$\mathrm{X}^{2} / \mathrm{df}=4.780$ \\
Probability level $=0.000$ \\
$\mathrm{GFI}=0.699$ \\
$\mathrm{CFI}=0.556$ \\
$\mathrm{RMSEA}=0.123$ \\
$\mathrm{NFI}=0.504$ \\
\hline
\end{tabular}

Standardized Regression Weights:

\begin{tabular}{llll}
\hline & & & Estimate \\
\hline Q53 & $<---$ & F1 & .771 \\
Q52 & $<--$ & F1 & .595 \\
Q51 & $<---$ & F1 & .895 \\
Q50 & $<--$ & F1 & .671 \\
Q49 & $<---$ & F1 & .343 \\
Q48 & $<---$ & F1 & -.084 \\
Q47 & $<--$ & F1 & -.155 \\
Q46 & $<---$ & F1 & -.062 \\
Q60 & $<---$ & F2 & .601 \\
Q59 & $<--$ & F2 & .767 \\
Q58 & $<---$ & F2 & .785 \\
Q57 & $<---$ & F2 & .443 \\
Q56 & $<---$ & F2 & .234 \\
Q55 & $<---$ & F2 & .487 \\
Q54 & $<--$ & F2 & .200 \\
Q68 & $<---$ & F3 & .264 \\
Q67 & $<---$ & F3 & .772 \\
Q66 & $<---$ & F3 & .855 \\
Q65 & $<---$ & F3 & .488 \\
Q64 & $<--$ & F3 & .616 \\
Q63 & $<---$ & F3 & .001 \\
Q62 & $<---$ & F3 & .231 \\
Q61 & $<---$ & F3 & .160 \\
\hline
\end{tabular}

Figure 4 . The construct validity of organizational involvement

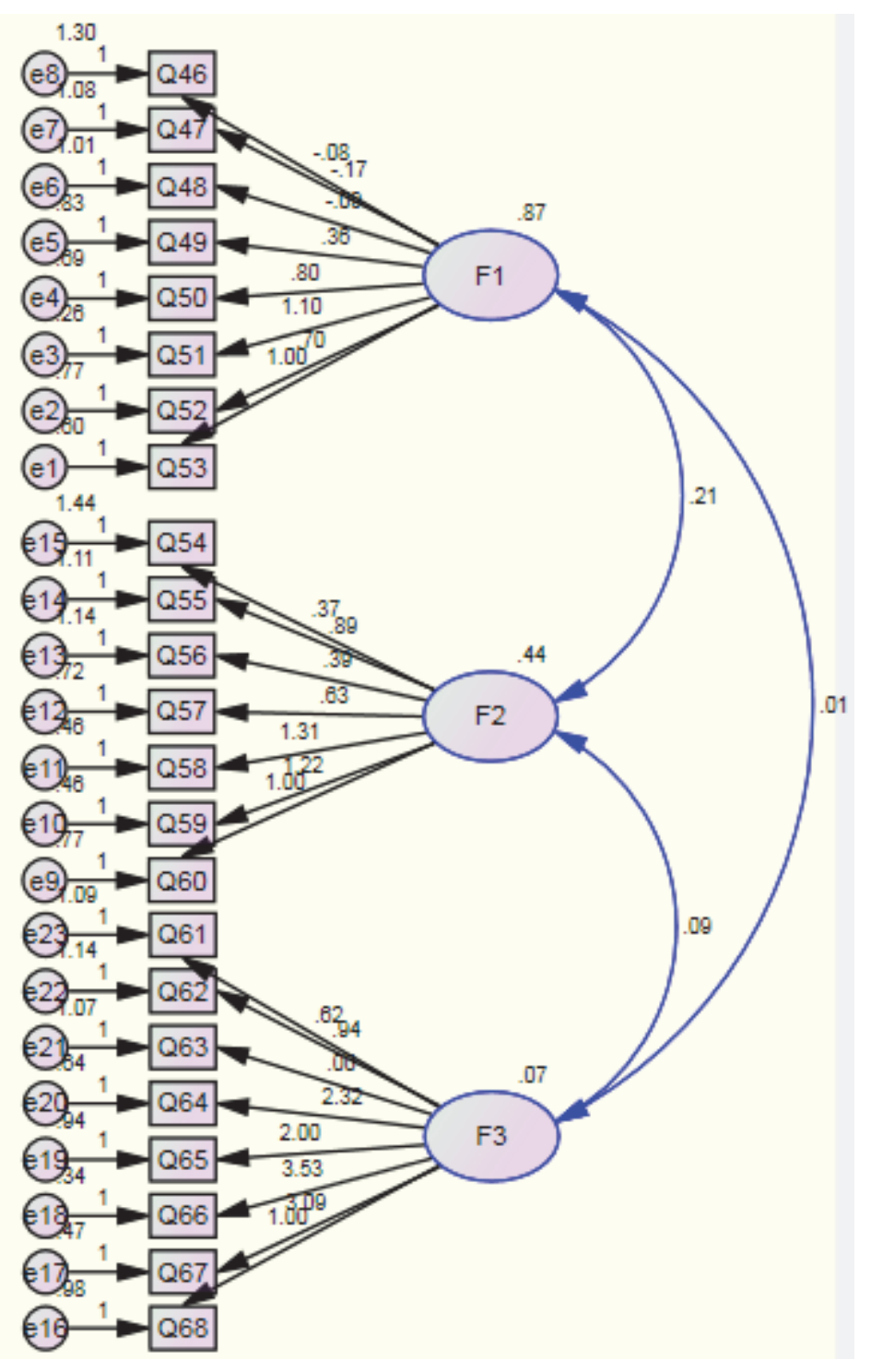

The results above show that the value of $\mathrm{Chi}^{2}$ is (1085.111) and it is significant at $(\alpha \leq 0.05)$. Also, the Minimum Discrepancy value $\left(\mathrm{Ch}^{2} / \mathrm{DF}\right)$ is (4.780) which specified that the harmonization level is good; where (Arbuckle, 2008) stated that the harmonization level range 1 to 5. The Goodness of Fit Index (GFI) which represent the harmonization of quality is (0.699) and this value is close to one (Full compatibility). The value of Comparative Fit Index (CFI) is (0.556) and it is also close to one. Furthermore, the result above shows that the value of Root Mean Square Error of Approximation (RMSEA) is (0.123) is close to zero. Also, the value of Normed Fit Index (NFI) is (0.504) and it is close to one. Additionally, the table above shows that the values of Standardized Regression Weight for Organization Performance are higher than (0.4) (Hair et al., 2010, p. 116). Accordingly, these results confirm the validity of Organization Performance. 


\subsubsection{Reliability of Scales}

Cronbach's alpha is used to measure the scale of reliability and to measure the internal stability and consistency of the study's measurement instrument, whereas (Pallant, 2005, p. 7) stated: "Ideally, the Cronbach alpha coefficient of a scale should be above 0.60 ". Table (2) indicates Cronbach alpha results.

Table 2. Cronbach's Alpha Coefficients

\begin{tabular}{lll}
\hline Study construct & Number of Items & Cronbach's Alpha Values \\
\hline Talent Attraction & 9 & 0.833 \\
Talent Maintenance & 6 & 0.842 \\
Talent Development & 10 & 0.938 \\
Talent Management (TM) & $\underline{25}$ & $\underline{0.932}$ \\
Professional -manager interaction & 7 & 0.888 \\
Pay & 5 & 0.609 \\
Supervisor-supervisee interaction & 5 & 0.846 \\
Job requirements & 3 & 0.648 \\
Job Satisfaction & 20 & 0.855 \\
Affective & 8 & 0.674 \\
Continuance & 7 & 0.692 \\
Normative & 8 & 0.679 \\
Organizational Involvement & 23 & 0.828 \\
Organizational Effectiveness (OE) & $\underline{43}$ & $\underline{0.881}$ \\
\hline
\end{tabular}

Apparently, from the above table that all the Cronbach's Alpha values were higher than (0.6), which is the minimum allowable limit as (Pallant, 2005) stated. This means that there is an inner consistency among the instrument questions and it has high reliability in order to accomplish this study's main objectives.

\section{Research Results}

\subsection{Descriptive Analysis}

In this study, the targeted respondent group were requested to provide information related to their demographic characteristics, such as; gender, age, qualification degree, job position, and experience tenure. The next table introduces the respondents' demographic data profile, besides the frequency and percentage of each variable.

Table 3. Research Respondents' Characteristics

\begin{tabular}{lll}
\hline Respondent's characteristics & Frequency & Percentages \\
\hline Gender & & \\
Male & 114 & 45.4 \\
Female & 137 & 54.6 \\
Age & & \\
Less than 25 & 53 & 21.1 \\
25 - less than 30 & 76 & 30.3 \\
30- less than 35 & 67 & 26.7 \\
35 and more & 55 & 21.9 \\
Qualification & & \\
Bachelor & 185 & 73.7 \\
Diploma & 14 & 5.6 \\
Master & 24 & 9.6 \\
PHD & 3 & 1.2 \\
Other & 25 & 10.0 \\
Position & & \\
Department Manager & 35 & 13.9 \\
Unit Manager & 4 & 1.6 \\
Supervisor & 10 & 4.0 \\
Employee & 202 & 80.5 \\
\hline
\end{tabular}




\begin{tabular}{lll}
\hline Experience Tenure & & \\
Less than 3 years & 82 & 32.7 \\
3 years - less than 6 years & 54 & 21.5 \\
6 years- less than 9 years & 40 & 15.9 \\
9 years and above & 75 & 29.9 \\
\hline
\end{tabular}

As presented in the above table, the demographic distribution of the respondents show that $(54.6 \%)$ of the sample items were females, and (45.4) were males. This proposes that the majority of the Jordanian private JCI accredited hospitals workers are females, which could be attributed to the fact that the health care sector is an attractive workplace, especially for females; and that the significant portion of the allied health sciences, nursing, and pharmaceutical sciences graduates are actually females. As for age distribution, the majority of the workers at the Jordanian private JCI accredited hospitals with a percentage of $(30.3 \%)$ belong to the age category of 25 -less than 30 years old. Followed by a (26.7\%) that belong to the age category 30 -less than 35 years old, then $(21.9 \%)$ who belong to the age category of 35 years old and more, and the lowest percentage of $(21.1 \%)$ of the workers are less than 25 year old. The indicators show good homogeneity of age groups within the Jordanian private JCI accredited hospitals workers, demonstrating that the questionnaires were distributed to the intended workers fairly.

Considering the educational level of the targeted sample, the majority of them hold Bachelor's degrees reaching (73.7\%) of the total workforce, with $(9.6 \%)$ holding a Master's degree, while a $(5.6 \%)$ holds higher education diploma degrees, and (1.2\%) holding a Ph.D. degree. Also, some of sampled employees held other degrees such as; college diploma or high school degree representing $(10 \%)$. These results indicate that most of the Jordanian private JCI accredited hospitals tend to hire individuals holding at least a Bachelor's degree.

Regarding the occupied positions by these sampled workers, a total $(80.5 \%)$ of the respondents were regular employees, varying between registered nurses, resident doctors, X-Ray technicians, medical recorders, and quality control officers, and such. While (13.9\%) of the remaining respondents held managerial positions, such as; patient affairs head, human resource managers, and general health and safety manager, etc., and (4\%) were supervisors, such as; the nursing supervisors, and the physiotherapy technicians supervisor, etc., $(1.6 \%)$ were units managers, such as; the nutrition and kitchen manager, the laundry manager, and the psychotherapy ward manager, etc., these outcomes indicate that the main organizational structure adopted at of the Jordanian private JCI accredited hospitals is the hierarchy structure.

Finally in terms of experience tenure, $(32.7 \%)$ of the sampled respondents have has experience for less than 3 years, followed by a $(29.9 \%)$ with over 9 years of experience, $(21.5 \%)$ with 3 to less than 6 years of experience, and a $(15.9 \%)$ with 6 to lower than 9 years of experience. These results indicate that there is a good diversity in regard to the tenure of experience of the sample respondents, and the Jordanian private JCI accredited hospitals considered as an attractive place to work within especially for the fresh graduate people and for the royal medical services retired people who have long and distinguished experiences.

\subsection{Descriptive Analysis for the Study Variables}

The researchers made a descriptive analysis for the study variables as presented at the tables below, in order to depict the respondents' answers and manners towards the questionnaire items. The means, the standard deviation, relative importance and the ranking were calculated for each study model variables and dimensions.

In order to determine the relative importance of the study variables at the descriptive tables, the researchers used a statistical index in respect of dividing the relative importance classifications into three criteria; high, medium, and low. In accordance with that, the used scale at the study questionnaire is "A five-point Likert scale" with the following format: "1: Strongly Disagree", "2: Disagree", "3: Moderately Agree", "4: Agree”, and "5: Strongly Agree", as the following equations:

Class Length $=$ upper limit - lower limit/number of relative importance levels

$$
\begin{array}{ll}
= & 5-1 / 3 \\
= & 1.33
\end{array}
$$

Thus the relative importance classifications will be as follow: 
Table 4. Interpretation for the Variables' Means

\begin{tabular}{cc}
\hline Scale Average & Classifications \\
\hline $1.00-2.33$ & Low \\
$2.34-3.67$ & Medium \\
$3.68-5$ & High \\
\hline
\end{tabular}

Table 5. Descriptive Statistics of Talent Attraction

\begin{tabular}{lllll}
\hline Talent Attraction & Mean & Std. Deviation & Relative Importance & RANK \\
\hline The organization, long-term manpower planning is done. & 3.29 & 1.074 & Medium & 7 \\
Organization, medium-term manpower planning is done. & 3.34 & 1.001 & Medium & 6 \\
Organization, staffing short-term planning is done. & 3.43 & 1.102 & Medium & 5 \\
The recruitment is done from sources outside the organization. & 3.06 & 1.177 & Medium & 8 \\
The recruitment is done from sources within the organization. & 3.46 & 1.109 & Medium & 4 \\
Skilled manpower is required to supply a regular basis. & 3.79 & 1.057 & High & 2 \\
Hired through employment tests were done. & 3.90 & 1.050 & High & 1 \\
The recruitment is done through employment interviews. & 3.55 & 1.213 & Medium & 3 \\
Recruitment is done through assessment centers. & 2.93 & 1.157 & Medium & 9 \\
Total & $\underline{3.42}$ & $\underline{0.717}$ & Medium & - \\
\hline
\end{tabular}

It can be seen from the table above that the overall attitude of the respondents towards the first dimension, Attracting Talent Management, of the first variable of talent management. Results showed that the highest arithmetic mean is (3.90), with a standard deviation (1.050), for the question item: "Hired through employment tests done", while the lowest arithmetic mean is (2.93), with a standard deviation (1.157), for the question item "Recruitment is done through assessment center". This indicates that the private Jordanian JCI accredited hospitals tend to employ their employees based on exams rather than using the assessment centers. With that given, the quality of their employees is supposed to be high, which in turn might satisfy the organization's needs. Additionally, hiring process based on selecting skillful workers to supply a regular basis of the organization.

Table 6. Descriptive Statistics of Talent Maintenance

\begin{tabular}{|c|c|c|c|c|}
\hline Talent Maintenance & Mean & $\begin{array}{l}\text { Std. } \\
\text { Deviation }\end{array}$ & $\begin{array}{l}\text { Relative } \\
\text { Importance }\end{array}$ & RANK \\
\hline $\begin{array}{l}\text { Talent in the organization, periodic performance evaluation is } \\
\text { done. }\end{array}$ & 3.29 & 1.114 & Medium & 2 \\
\hline In the organization, there is 360 degrees feedback. & 3.07 & 1.120 & Medium & 4 \\
\hline $\begin{array}{l}\text { The value of the Organization of the competencies of their } \\
\text { employees. }\end{array}$ & 3.82 & 1.163 & High & 1 \\
\hline The organization strives to identify potential talents. & 3.26 & 1.008 & Medium & 3 \\
\hline $\begin{array}{l}\text { The organization paid based on the knowledge, skills, and } \\
\text { experience of its employees. }\end{array}$ & 2.90 & 1.176 & Medium & 6 \\
\hline The payment is based on achieving the set goals. & 2.94 & 1.088 & Medium & 5 \\
\hline Total & 3.22 & $\underline{0.832}$ & Medium & - \\
\hline
\end{tabular}

As it is declared at the table above, the overall attitude for the respondents with regard to the second dimension, Maintain Talent Management, of the first variable talent management. Results exhibited the highest arithmetic mean is (3.82), with a standard deviation (1.163), for the question item: "The value of the Organization of the competencies of their employees.", while the lowest arithmetic mean is (2.90), with a standard deviation (1.176), for the question item "The organization paid based on the knowledge, skills, and experience of its employees". This infers that the real invaluable asset at the private Jordanian JCI accredited hospitals centered on their human resource capabilities, and has evolved by making performance evaluation on a periodical basis and considering the stakeholder's feedback, which helps in identifying the talented employees more specifically. 
Table 7. Descriptive Statistics of Talent Development

\begin{tabular}{|c|c|c|c|c|}
\hline Talent Management Development & Mean & $\begin{array}{l}\text { Std. } \\
\text { Deviation }\end{array}$ & $\begin{array}{l}\text { Relative } \\
\text { Importance }\end{array}$ & RANK \\
\hline $\begin{array}{l}\text { The organization focuses on the needs assessment for } \\
\text { courses. }\end{array}$ & 3.24 & 1.059 & Medium & 6 \\
\hline $\begin{array}{l}\text { The organization held training courses, and programs } \\
\text { with certifications. }\end{array}$ & 3.31 & 1.043 & Medium & 5 \\
\hline The organization held training courses on a regular basis. & 3.22 & 1.071 & Medium & 8 \\
\hline $\begin{array}{l}\text { In the organization, the staff is trained on the required } \\
\text { perceptual skills. }\end{array}$ & 3.14 & 1.034 & Medium & 10 \\
\hline $\begin{array}{l}\text { In the organization, the staff is trained on the required } \\
\text { human skills. }\end{array}$ & 3.24 & 1.070 & Medium & 7 \\
\hline $\begin{array}{l}\text { An organization's employees are taught the needed } \\
\text { technical skills. }\end{array}$ & 3.37 & 1.016 & Medium & 3 \\
\hline In an organization, there is continuous learning. & 3.38 & 1.037 & Medium & 2 \\
\hline $\begin{array}{l}\text { The organization encourages the continuous learning on the } \\
\text { job. }\end{array}$ & 3.39 & 1.035 & Medium & 1 \\
\hline $\begin{array}{l}\text { In the organization, according to mutual need units to talent, } \\
\text { career organization is adjusted. }\end{array}$ & 3.33 & 0.899 & Medium & 4 \\
\hline $\begin{array}{l}\text { Promote talented individuals within the organization is done } \\
\text { with consideration of the needs of education. }\end{array}$ & 3.16 & 1.139 & Medium & 9 \\
\hline Total & $\underline{3.28}$ & $\underline{0.835}$ & Medium & - \\
\hline
\end{tabular}

As it is declared by the table above, the overall attitude for the respondents with regard to the third dimension, Develop Talent Management, of the first variable talent management. These results exhibited that the highest arithmetic mean is (3.39), with a standard deviation (1.035), for the question item: "The organization encourages the continuous learning on the job.", and the lowest arithmetic mean is (3.14), with a standard deviation (1.034), for the question item "In the organization, the staff is trained on the required perceptual skills". These observations indicate that in order to develop the talented employees, the private Jordanian JCI accredited hospitals tend to encourage their employees to feed their knowledge either by holding higher scientific degrees, attending related training courses, workshops, and lectures. It turns out that all the intended hospitals also have a "Continues Learning Unit", which is specified to the nursing staff and takes the responsibility to evolve their skills and capabilities to stay updated with the nursing field.

Table 8. Descriptive Statistics of Talent Management

\begin{tabular}{llll}
\hline Talent Management & Mean & Std. Deviation & Relative Importance \\
\hline Talent Management & 3.30 & 0.668 & Medium \\
\hline
\end{tabular}

In conclusion, the overall obtained results showed that the targeted sample had, in some way or another, positive answers towards the questionnaire questions applied to the independent variable "Talent Management" with an arithmetic mean equals to (3.30) and a standard deviation (0.668).This indicates that the intended hospitals are aware of the huge importance of their employees, using multi ways to attract the potential talented people, and considering them as a solid asset to qualify their organizations to gain a competitive advantage, as they seek to develop the capabilities of talented employees for the benefit of the two.

Table 9. Descriptive Statistics of Job Satisfaction-Professional and Manager Interaction

\begin{tabular}{|c|c|c|c|c|}
\hline $\begin{array}{l}\text { Job Satisfaction } \\
\text { Professional and Manager Interaction }\end{array}$ & Mean & $\begin{array}{l}\text { Std. } \\
\text { Deviation }\end{array}$ & $\begin{array}{l}\text { Relative } \\
\text { Importance }\end{array}$ & RANK \\
\hline $\begin{array}{l}\text { Managers, in general, cooperate with professionals where I } \\
\text { work. }\end{array}$ & 3.43 & 1.050 & Medium & 4 \\
\hline $\begin{array}{l}\text { There is a lot of teamwork between professionals and } \\
\text { managers in my unit. }\end{array}$ & 3.71 & 0.978 & High & 1 \\
\hline $\begin{array}{l}\text { Managers where I work generally understand and appreciate } \\
\text { what professionals do. }\end{array}$ & 3.46 & 1.032 & Medium & 3 \\
\hline
\end{tabular}




\begin{tabular}{|c|c|c|c|c|}
\hline $\begin{array}{l}\text { I have sufficient say in policies and procedures that impact my } \\
\text { work in my organization. }\end{array}$ & 3.55 & 0.955 & Medium & 2 \\
\hline $\begin{array}{l}\text { I have all the voice in planning and procedures where I work } \\
\text { that I want. }\end{array}$ & 3.15 & 1.066 & Medium & 5 \\
\hline $\begin{array}{l}\text { Where I work, there is ample opportunity for professionals to } \\
\text { participate in the administrative decision-making process. }\end{array}$ & 2.90 & 1.127 & Medium & 7 \\
\hline $\begin{array}{l}\text { A great deal of independence is permitted if not required of me } \\
\text { where I work. }\end{array}$ & 3.05 & 1.096 & Medium & 6 \\
\hline Total & 3.32 & 0.808 & Medium & - \\
\hline
\end{tabular}

As noted above, the overall responses from respondents with regard to the first element, Professional and Manager Interaction, of the first dimension Job Satisfaction under the second variable Organizational Effectiveness. The outcomes showed that the highest arithmetic mean is (3.71), with a standard deviation (0.978), for the question item: "There is a lot of teamwork between professionals and managers in my unit". The lowest arithmetic mean is (2.90), with a standard deviation (1.127), for the question item "Where I work, there is ample opportunity for professionals to participate in the administrative decision-making process". This indicates that the majority of the private Jordanian JCI accredited hospitals employees work within teams, and there is active communication and cooperation among them and their managers, in addition, the employees' opinions are considered in regard to their departments' policies and decisions since the employees' performance is valued by the manager.

Table 10. Descriptive Statistics of Job Satisfaction-Pay

\begin{tabular}{|c|c|c|c|c|}
\hline $\begin{array}{l}\text { Job Satisfaction } \\
\text { Pay }\end{array}$ & Mean & $\begin{array}{l}\text { Std. } \\
\text { Deviation }\end{array}$ & $\begin{array}{l}\text { Relative } \\
\text { Importance }\end{array}$ & RANK \\
\hline My present pay is satisfactory. & 4.57 & 0.520 & High & 1 \\
\hline $\begin{array}{l}\text { An upgrade of pay rates for professionals in my organization is } \\
\text { needed in my opinion. }\end{array}$ & 4.41 & 0.690 & High & 2 \\
\hline $\begin{array}{l}\text { Considering what is expected of me where I work, the pay I get } \\
\text { is reasonable. }\end{array}$ & 4.20 & 0.741 & High & 4 \\
\hline $\begin{array}{l}\text { The present rate of increase in pay for professionals where I } \\
\text { work is not satisfactory. }\end{array}$ & 4.27 & 0.724 & High & 3 \\
\hline $\begin{array}{l}\text { Compared to professionals at other places, where I work our } \\
\text { pay is fair. }\end{array}$ & 4.19 & 0.766 & High & 5 \\
\hline Total & 4.33 & 0.433 & High & - \\
\hline
\end{tabular}

The table above shows that the overall answers of the targeted sample with regard to the second element, Pay of the first dimension job satisfaction, under the second variable of Organizational Effectiveness. The outcomes show that the highest arithmetic mean is (4.57), with a standard deviation (0.520), for the question item: "My present pay is satisfactory." and the lowest arithmetic mean is (4.19), with a standard deviation (0.766), for the question item "Compared to professionals at other places, where I work our pay is fair". This indicates that the majority of the private Jordanian JCI accredited hospitals tend to give a good and satisfactory payment amounts to their employees incomparison to counterpart workplaces, and per contra, the employees at the intended hospitals consider their salaries fair too.

Table 11. Descriptive Statistics of Job Satisfaction- Supervisor-Supervisee Interaction

\begin{tabular}{llllc}
\hline $\begin{array}{l}\text { Job Satisfaction } \\
\text { Supervisor-Supervisee Interaction }\end{array}$ & Mean & $\begin{array}{l}\text { Std. } \\
\text { Deviation }\end{array}$ & $\begin{array}{l}\text { Relative } \\
\text { Importance }\end{array}$ & RANK \\
\hline $\begin{array}{l}\text { There is a good deal of teamwork and cooperation } \\
\text { between supervisors and supervisees on my job. }\end{array}$ & 3.41 & 1.021 & Medium & 5 \\
$\begin{array}{l}\text { Professional personnel in my organization do not hesitate } \\
\text { to follow orders. }\end{array}$ & 3.52 & 0.922 & Medium & 3 \\
$\begin{array}{l}\text { Supervisees show a great deal of respect for supervisors. } \\
\text { Supervisees, where I work, understand and appreciate }\end{array}$ & 3.68 & 0.892 & High & 2 \\
\hline
\end{tabular}




\begin{tabular}{|c|c|c|c|c|}
\hline $\begin{array}{l}\text { what supervisors do. } \\
\text { I feel I have sufficient input into the program of work for } \\
\text { each of my clients/ customers. }\end{array}$ & 3.82 & 0.923 & High & 4 \\
\hline Total & 3.59 & 0.737 & Medium & - \\
\hline
\end{tabular}

The table above demonstrates that the overall answers of the targeted sample with regard to the third element Supervisor-supervisee interaction of the first dimension Job Satisfaction under the second variable of Organizational Effectiveness. The results show that the highest arithmetic mean is (3.82), with a standard deviation (0.923), for the question item: "I feel I have sufficient input into the program of work for each of my clients/ customers.", while the lowest arithmetic mean is (3.41), with a standard deviation (1.021), for the question item "There is a good deal of teamwork and cooperation between supervisors and supervisees on my job". This indicates that the majority of the private Jordanian JCI accredited hospitals employees are fully loaded with their hospital job system associated with the related clients, and those employees feel appreciated by their supervisors. On the other hand, they don't hesitate to follow orders and instructions within the hospital.

Table 12. Descriptive Statistics of Job Satisfaction- Job Requirements

\begin{tabular}{lllll}
\hline $\begin{array}{l}\text { Job Satisfaction } \\
\text { Job Requirements }\end{array}$ & Mean & $\begin{array}{l}\text { Std. } \\
\text { Deviation }\end{array}$ & $\begin{array}{l}\text { Relative } \\
\text { Importance }\end{array}$ & RANK \\
\hline $\begin{array}{l}\text { I think I could do a better job if I didn't have so } \\
\text { much to do all the time. }\end{array}$ & 3.71 & 0.925 & High & 1 \\
$\begin{array}{l}\text { Administrative decisions where I work interfere too } \\
\text { much with client/customer care. }\end{array}$ & 3.42 & 0.994 & Medium & 3 \\
$\begin{array}{l}\text { I could deliver much better work results if I had } \\
\text { more time with each client/ customer. }\end{array}$ & 3.56 & 0.984 & Medium & \\
Total & $\underline{3.56}$ & $\underline{0.742}$ & $\underline{\text { Medium }}$ & - \\
\hline
\end{tabular}

The table above stated that the overall answers of the targeted sample with regard to the fourth element, Job requirements, of the first dimension Job Satisfaction; under the second variable of Organizational Effectiveness. The outcomes declare that the highest arithmetic mean is (3.71), with a standard deviation of (0.925), for the question item: "I think I could do a better job if I didn't have so much to do all the time". The lowest arithmetic mean is (3.42), with a standard deviation of (0.994), for the question item "Administrative decisions where I work interfere too much with client/customer care". This means that the majority of the private Jordanian JCI accredited hospitals employees feel they continuously have busy schedules, especially for the nursing staff who have unexpected and urgent rush hours. In general, employees claim that they can perform better if they are able to spend more time with each client, or if they have fewer workloads.

Table 13. Descriptive Statistics of Organizational Involvement-Affective

\begin{tabular}{|c|c|c|c|c|}
\hline Organizational Involvement Affective & Mean & $\begin{array}{l}\text { Std. } \\
\text { Deviation }\end{array}$ & $\begin{array}{l}\text { Relative } \\
\text { Importance }\end{array}$ & RANK \\
\hline $\begin{array}{l}\text { I would be very happy to spend the rest of my } \\
\text { career with this organization. }\end{array}$ & 2.93 & 1.145 & Medium & 5 \\
\hline $\begin{array}{l}\text { I enjoy discussing my organization with people } \\
\text { outside it. }\end{array}$ & 3.24 & 1.055 & Medium & 3 \\
\hline $\begin{array}{l}\text { I really feel as if this organization's problems are } \\
\text { my own. }\end{array}$ & 3.40 & 1.012 & Medium & 1 \\
\hline $\begin{array}{l}\text { I think that I could easily become as attached to } \\
\text { another organization as I am to this one. }\end{array}$ & 3.37 & 0.973 & Medium & 2 \\
\hline I do not feel like 'part of the family' at my organization. & 2.57 & 1.120 & Medium & 7 \\
\hline I do not feel 'emotionally attached' to this organization. & 2.72 & 1.147 & Medium & 6 \\
\hline This organization has a great deal of personal meaning for me. & 2.94 & 1.096 & Medium & 4 \\
\hline I do not feel a strong sense of belonging to my organization. & 2.51 & 1.214 & Medium & 8 \\
\hline Total & $\underline{2.96}$ & $\underline{0.606}$ & $\underline{\text { Medium }}$ & - \\
\hline
\end{tabular}


The table above indicates that the overall answers of the targeted sample with regard to the first element, the Affective aspect, of the second dimension Organizational Involvement under the second variable of Organizational Effectiveness. Results show that the highest arithmetic mean is (3.40), with a standard deviation of (1.012), for the question item: "I really feel as if this organization's problems are my own.", and that the lowest arithmetic mean is (2.51), with a standard deviation of (1.214), for the question item "I do not feel a strong sense of belonging to my organization". This means that the sampled employees at the intended hospitals are to some extent engaged with their organizations affectively, in terms that they are provided with chance to chat around with people about their workplace, and are even engaged with concerns about their hospital issues. However, this doesn't imply that they will not feel the same if they moved to another organization.

Table 14. Descriptive Statistics of Organizational Involvement-Continuance

\begin{tabular}{|c|c|c|c|c|}
\hline Organizational Involvement Continuance & Mean & $\begin{array}{l}\text { Std. } \\
\text { Deviation }\end{array}$ & $\begin{array}{l}\text { Relative } \\
\text { Importance }\end{array}$ & RANK \\
\hline $\begin{array}{l}\text { I am not afraid of what might happen if I quit my job } \\
\text { without having another one lined up. }\end{array}$ & 2.80 & 1.229 & Medium & 8 \\
\hline $\begin{array}{l}\text { Too much in my life would be disrupted if I } \\
\text { decided I wanted to leave my organization now. }\end{array}$ & 3.06 & 1.210 & Medium & 6 \\
\hline $\begin{array}{l}\text { It wouldn't be too costly for me to leave my organization } \\
\text { now. }\end{array}$ & 2.87 & 1.103 & Medium & 7 \\
\hline $\begin{array}{l}\text { Right now, staying with my organization is a } \\
\text { matter of necessity as much as desire. }\end{array}$ & 3.60 & 0.947 & Medium & 1 \\
\hline $\begin{array}{l}\text { I feel that I have too few options to consider } \\
\text { leaving this organization. }\end{array}$ & 3.10 & 1.101 & Medium & 5 \\
\hline $\begin{array}{l}\text { One of the few serious consequences of leaving } \\
\text { this organization would be the scarcity of } \\
\text { available alternatives. }\end{array}$ & 3.14 & 1.053 & Medium & 3 \\
\hline $\begin{array}{l}\text { One of the major reasons I continue to work for } \\
\text { this organization is that leaving would require } \\
\text { considerable personal sacrifice-another organization may } \\
\text { not match the overall benefits } \\
\text { I have. }\end{array}$ & 3.17 & 1.102 & Medium & 2 \\
\hline $\begin{array}{l}\text { I am not afraid of what might happen if I quit my job } \\
\text { without having another one lined up. }\end{array}$ & 3.11 & 0.658 & Medium & 4 \\
\hline Total & $\underline{2.80}$ & 1.229 & Medium & - \\
\hline
\end{tabular}

The table above stated that the overall answers of the targeted sample with regard to the second element, the Continuance aspect, of the second dimension Organizational Involvement under the second variable of Organizational Effectiveness. These indicators show that the highest arithmetic mean is (3.60), with a standard deviation of (0.947), for the question item: "Right now, staying with my organization is a matter of necessity as much as desire.", and that the lowest arithmetic mean is (2.80), with a standard deviation of (1.229), for the question item "I am not afraid of what might happen if I quit my job without having another one lined up". This indicates that the targeted employees hold their current positions as both; a necessity to work and their willingness to stay in such organization. In addition, one of the major reasons for continuing to work for their organizations is that leaving would imply considerable personal sacrifices, whereas other organization may not provide the overall benefits they are being offered by their current employers. However, if their leaving to another organization was planned, then the new one must be offering them the same, or even a better, and offer to work with.

Table 15. Descriptive Statistics of Organizational Involvement-Normative

\begin{tabular}{lclll}
\hline Organizational Involvement Normative & Mean & $\begin{array}{l}\text { Std. } \\
\text { Deviation }\end{array}$ & $\begin{array}{l}\text { Relative } \\
\text { Importance }\end{array}$ & RANK \\
\hline $\begin{array}{l}\text { I think that people these days move from } \\
\text { company to company too often. }\end{array}$ & 3.31 & 1.061 & Medium & 1 \\
I do not believe that a person must always be & 2.54 & 1.100 & Medium & 8 \\
\hline
\end{tabular}




\begin{tabular}{|c|c|c|c|c|}
\hline loyal to his or her organization. & & & & \\
\hline $\begin{array}{l}\text { Jumping from organization to organization does } \\
\text { not seem at all unethical to me. }\end{array}$ & 3.27 & 1.038 & Medium & 3 \\
\hline One of the major reasons I continue to work for & & & Medium & 2 \\
\hline $\begin{array}{l}\text { this organization is that I believe that loyalty is important and } \\
\text { therefore feel a sense of moral obligation to remain. }\end{array}$ & 3.30 & 1.021 & & \\
\hline $\begin{array}{l}\text { If I got another offer for a better job elsewhere I would not feel } \\
\text { it was right to leave my organization. }\end{array}$ & 2.92 & 1.114 & Medium & 7 \\
\hline $\begin{array}{l}\text { I was taught to believe in the value of remaining loyal to one } \\
\text { organization. }\end{array}$ & 3.01 & 1.121 & Medium & 6 \\
\hline $\begin{array}{l}\text { Things were better in the days when people stayed with one } \\
\text { organization for most of their careers. }\end{array}$ & 3.20 & 1.086 & Medium & 4 \\
\hline $\begin{array}{l}\text { I do not think that wanting to be a "company man" or } \\
\text { "company woman" is sensible anymore. }\end{array}$ & 3.18 & 1.028 & Medium & 5 \\
\hline Total & 3.09 & 0.595 & Medium & \\
\hline
\end{tabular}

The previous table stated that the overall responses of the targeted sample with regard to the third element, the Normative aspect, of the second dimension Organizational Involvement under the second variable of Organizational Effectiveness. Results show that the highest arithmetic mean is (3.31), with a standard deviation (1.061), for the question item: "I think that people these days move from company to company too often". The lowest arithmetic mean is (2.54), with a standard deviation of (1.100), for the question item "I do not believe that a person must always be loyal to his or her organization". These outcomes indicate that the targeted employees at the intended hospitals aren't prevented from leaving their current organization to other one due to legal issues; neither related to any unethical actions. Leaving is justified rather by a better job offer, and this explains the high turnover rates at the private Jordanian JCI accredited hospitals particularly. In contrast, a good portion of the respondents appointed that one of the major reasons why they continue working for their current hospital is that they believe that loyalty is important, and therefore, they feel a sense of moral obligation to remain regardless of any circumstances.

Table 16. Descriptive Statistics of Organizational Effectiveness

\begin{tabular}{lclll}
\hline Talent Management & Mean & $\begin{array}{l}\text { Std. } \\
\text { Deviation }\end{array}$ & $\begin{array}{l}\text { Relative } \\
\text { Importance }\end{array}$ & RANK \\
\hline Job Satisfaction & 3.70 & 0.463 & High & 1 \\
Organizational Involvement & 3.05 & 0.501 & Medium & 2 \\
\hline
\end{tabular}

In conclusion, the overall obtained results showed that the sampled employees somehow hold a positive attitude towards the questionnaire questions applied to the dependent variable "Organizational Effectiveness", with an arithmetic mean for the first dimension, the Job Satisfaction; which equals(3.70), with a standard deviation (0.463). In addition, they showed positive attitudes towards the second dimension, Organizational Involvement, with an arithmetic mean which equals (3.05),with a standard deviation (0.501).The obtained results from this table indicate that the private Jordanian JCI accredited hospitals are committed to achieving a better job satisfaction conditions for their employees for the benefit of the two parties, the employees and the hospital, which could be reflected on the employees' degree of involvement with their current workplaces.

\subsection{The Analysis of Multicollinearity}

Before testing the study hypotheses, the researchers must assert on the links between the study variables, and confirm that the collinearity among these variables is not high, whereas its value must not exceed (0.9).These need to be checked in order to avoid the probability of resulting in a total correlation, because if it happens; it will cause a linear interference problem among the study variables (Pallant, 2005). Therefore, a multicollinearity analysis test was conducted. In addition, the researchers tend to make a multicollinearity analysis test in order to confirm the descriptive data analysis results, as if there was relevance between the study variables; it doesn't necessarily mean that there is an effect between the two variables. Meanwhile, if there was an effect from one variable on another; it is necessary then to those determined variables to have relevance. Aside from, Pearson Correlation Coefficient was estimated for the main variables, since the Study data followed the normal distribution, as follow: 
Table 17. Correlations

\begin{tabular}{|c|c|c|c|c|c|c|}
\hline & & $\begin{array}{l}\text { Organizational } \\
\text { Effectiveness }\end{array}$ & $\begin{array}{l}\text { Talent } \\
\text { Management }\end{array}$ & $\begin{array}{l}\text { Attract } \\
\text { Talent }\end{array}$ & $\begin{array}{l}\text { Maintain } \\
\text { Talent }\end{array}$ & Develop Talent \\
\hline \multirow{4}{*}{$\begin{array}{l}\text { Organizational } \\
\text { Effectiveness }\end{array}$} & Pearson & 1 & $.555^{* *}$ & $.439 * *$ & $.482 * *$ & $.475 * *$ \\
\hline & Correlation & & & & & \\
\hline & Sig. (2-tailed) & & 0.000 & .000 & .000 & .000 \\
\hline & $\mathrm{N}$ & 251 & 251 & 251 & 251 & 251 \\
\hline \multirow{4}{*}{$\begin{array}{l}\text { Talent } \\
\text { Management }\end{array}$} & Pearson & $.555^{* *}$ & 1 & $.787^{* *}$ & $.876^{* *}$ & $.852^{* *}$ \\
\hline & Correlation & & & & & \\
\hline & Sig. (2-tailed) & .000 & & . 000 & .000 & .000 \\
\hline & $\mathrm{N}$ & 251 & 251 & 251 & 251 & 251 \\
\hline \multirow[t]{3}{*}{ Attract Talent } & $\begin{array}{l}\text { Pearson } \\
\text { Correlation }\end{array}$ & $.439^{* *}$ & $.787^{* *}$ & 1 & $.550^{* *}$ & $.482^{* *}$ \\
\hline & Sig. (2-tailed) & .000 & .000 & & .000 & .000 \\
\hline & $\mathrm{N}$ & 251 & 251 & 251 & 251 & 251 \\
\hline \multirow[t]{3}{*}{ Maintain Talent } & $\begin{array}{l}\text { Pearson } \\
\text { Correlation }\end{array}$ & $.482^{* *}$ & $.876^{* *}$ & $.550^{* *}$ & 1 & $.634^{* *}$ \\
\hline & Sig. (2-tailed) & .000 & .000 & .000 & & .000 \\
\hline & $\mathrm{N}$ & 251 & 251 & 251 & 251 & 251 \\
\hline \multirow[t]{3}{*}{ Develop Talent } & $\begin{array}{l}\text { Pearson } \\
\text { Correlation }\end{array}$ & $.475^{* *}$ & $.852^{* *}$ & $.482^{* *}$ & $.634^{* *}$ & 1 \\
\hline & Sig. (2-tailed) & .000 & .000 & .000 & . 000 & \\
\hline & $\mathrm{N}$ & 251 & 251 & 251 & 251 & 251 \\
\hline
\end{tabular}

**. Correlation is significant at the 0.01 level (2-tailed).This table suggests that the study independent variable, Talent Management, including its three dimensions; Attract Talent, Maintain Talent, and Develop Talent, have a statistically significant value over the dependent variable Organizational Effectiveness at a significant level equals to (0.01). The results also indicate that the Talent Management variable has a strong effect on the Organizational Effectiveness variable with a significance level at $(r=0.555)$. Finally, results indicate no total correlation among the study variables.

\subsection{The Inferential Analysis: Hypotheses Testing}

In this section, the researchers test the developed hypotheses in this study in order to determine whether to accept or reject them. Thus, both simple and multiple regression analyses tests were estimated by the SPSS, version 19. A confidence level at (95\%) was chosen, hence, the significance level of $(0.05)$ was determined. The null hypotheses were accepted or rejected with a declaration. However, before performing a Collinearity Diagnostic test, whereas the Variance Inflation Factor test (VIF) at the following table represents that all values were less than (10). These indicators show that there is no issue with applying the Collinearity Diagnostic among the study independent variable dimensions, as it stated by Pallant (2005). Also, it represents the (Tolerance) values which act as indexes for the linear relationship among the dimensions of the independent variable, which is generally accepted if it was greater than $(0.1)$ as it is equal to the inverse coefficient of variance inflation ( $1 /$ VIF ).

Table 18. Variance Inflation Factor

\begin{tabular}{lll}
\hline \multicolumn{2}{l}{ Collinearity statistics } & Variables \\
\hline$\underline{\mathrm{VIF}}$ & $\underline{\text { Tolerance }}$ & \\
1.479 & 0.668 & Attract Talent \\
1.922 & 0.520 & Maintain Talent \\
1.747 & 0.572 & Develop Talent \\
\hline
\end{tabular}

The above results clarify that the (VIF) values range between 1.479 and 1.922 , noting that these values are less than (10). Also it shows that the (Tolerance) values were higher than $(0.1)$, and that means that there is no issue in relation with the correlation diagnostic among the independent variable dimensions. Therefore, a hypotheses testing could be estimated now easily. 


\subsection{Multiple Regression Analysis}

The main goal of conducting this study is to test the effect of talent management over the organizational effectiveness at the Jordanian private JCI accredited hospitals; the following represent the study's results.

Table 19. Multiple Regression Analysis

\begin{tabular}{|c|c|c|c|c|c|c|c|c|}
\hline \multirow{3}{*}{$\begin{array}{l}\text { Independent } \\
\text { Variable } \\
\text { Dimensions }\end{array}$} & \multicolumn{3}{|c|}{ Model summary } & \multicolumn{2}{|l|}{ ANOVA } & \multicolumn{2}{|c|}{ Coefficients(a) } & \multirow{2}{*}{$\begin{array}{l}\text { Unstandar-dized } \\
\text { coefficients } \\
\text { Beta }\end{array}$} \\
\hline & $\mathrm{R}$ & R Square & $\begin{array}{l}\text { Adjusted R } \\
\text { Square }\end{array}$ & F-value & Sig & $\mathrm{T}$ & Sig.(P-value) & \\
\hline & 0.555 & 0.308 & 0.300 & 36.651 & 0.000 & & & \\
\hline Constant & & & & & & 16.036 & 0.000 & 2.023 \\
\hline $\begin{array}{l}\text { Attract } \\
\text { Talent }\end{array}$ & & & & & & 3.156 & 0.002 & 0.129 \\
\hline Maintain Talent & & & & & & 2.992 & 0.003 & 0.120 \\
\hline Develop Talent & & & & & & 3.386 & 0.001 & 0.129 \\
\hline
\end{tabular}

It can be noticed from the result from the table above that the multiple correlation coefficients equal to $(\mathrm{R}=$ 0.555), which indicates that there is a strong positive correlation between the study variables; Talent management and Organizational Effectiveness. Also, table provides the value of $\left(\mathrm{R}^{2}=0.308\right)$, which means that the Talent Management can account for (0.555) of the variation of the Organizational Effectiveness. Furthermore, it is noticed that the value of adjusted $\mathrm{R}^{2}$ is very close to the value of $\mathrm{R}^{2}$. If the adjusted $\mathrm{R}^{2}$ is excluded from $\mathrm{R}^{2}$ $(0.308-0.300)=0.008$. This little shrinking of $(0.008)$ means that if the model has been fitted when the whole population participates in the study, the higher variance in the outcome will be 0.008 .

Also, the table above shows the probability of F-value and that it is significant at 0.05 , which indicates that Talent Management with its dimensions; Talent Attraction, Maintain Talent, and Talent Development, have a significant effect on Organizational Effectiveness at $(\alpha \leq 0.05)$. Therefore, the first null main hypothesis is rejected and the alternative is accepted with the statistically significant effect at the level $(\alpha \leq 0.05)$ by talent management on organizational effectiveness. Referring to the first sub-hypothesisH1.1; the sig value of Attract Talent is (0.002), and it is significant at $(\alpha \leq 0.05)$.In addition, the t-calculated is (3.156) and it is higher than the $\mathrm{t}$-tabulated (1.96), and the impact value (Beta) is (0.129); that is if the value of attract talent increased by one unit, it is expected to increase the dependent variable (organizational effectiveness) by (0.129) with stability of the other variables. This indicates that the first dimension "Attract Talent" has a significant effect on the Organizational Effectiveness at $(\alpha \leq 0.05)$. Therefore, the first sub-hypothesis is rejected and the alternative is accepted with a statistically significant effect at $(\alpha \leq 0.05)$ of Attract Talent on Organizational Effectiveness. Referring to the second sub-hypothesisH1.2; the sig value of Maintain Talent is $(0.003)$ and it is significant at ( $\alpha$ $\leq 0.05)$ and the t-calculated is (2.992) and it is higher than the t-tabulated (1.96), and the impact value (Beta) is $(0.120)$; that is if the value of maintain talent increased by one unit, it is expected to increase the dependent variable (organizational effectiveness) by $(0.120)$ with stability of the other variables. This indicates that the second dimension "Maintain Talent" has a significant effect on the Organizational Effectiveness at $(\alpha \leq 0.05)$. Therefore, the second sub-hypothesis is rejected and the alternative is accepted (There is a statistically significant effect) at $(\alpha \leq 0.05)$ of Maintain Talent on Organizational Effectiveness. Referring to the second sub-hypothesisH1.3; the sig value of Talent Development is (0.001), and it is significant at $(\alpha \leq 0.05)$. The $\mathrm{t}$-calculated is (3.386) and it is higher than the t-tabulated (1.96), and the impact value (Beta) is (0.129); that is if the value of develop talent increased by one unit, it is expected to increase the dependent variable (organizational effectiveness) by (0.129) with stability of the other variables. This indicates that the last dimension "Talent Development" has a significant effect on the Organizational Effectiveness at $(\alpha \leq 0.05)$. Therefore, the third sub-hypothesis is rejected and the alternative is accepted with a statistically significant effect at $(\alpha \leq 0.05)$ of developing the talent on Organizational Effectiveness.

\section{Conclusion}

Viewing the literature findings on talent management relation with organizational effectiveness, there is a quiet limited number of published research studies related this paper subject and particularly related to the Jordanian health care sector. Therefore, this study aims at reducing the gap in such a service-oriented domain by examining the effect of talent management on organizational effectiveness at the private hospitals that hold JCI accreditation in Jordan. In this paper, the researchers give this study a conclusion in two main parts; the study's 
main findings, the study's contributions. Finally, the study implications, limitations, and future recommendations are provided.

\subsection{Implications of the Findings}

Organizations must view their employees as their success backbone, and thus evaluating the talents, preserving and improving the process will pour into the organizational overall benefit (see e.g. AlHarrasi \& AL-Lozi, 2015; AlHarrasi et al., 2016; AL-Syaidh et al., 2016; Darawsheh et al., 2016; Alkandari et al., 2017; Khalayleh et al., 2017; Abualoush et al., 2018a, 2018b; Al-dalahmeh et al., 2018; Masa'deh, et al., 2018). In this study, the researchers test whether there is an effect by the talent management on the organizational effectiveness or not in health care field, taking the Jordanian private JCI accredited hospitals workers in specific as the targeted study population. The study examined the perspective of talent management three dimensions influence over the organizational effectiveness over the intended hospital's workers. The literature review stated that the attraction, the maintenance, and the development of talent management are prime dimensions to estimate talent management. Five private JCI accredited hospitals in Jordan were chosen for the survey of this study.

Throughout the codified previous studies, in order to acquire a competitive advantage in the susceptible business domain at the local health care private service sector, hospitals have a wide area for exploitation and improvement their significant human resource asset, which is justifying the shifting from applying the classic human resource processes and activities into acquiring and developing human resource strategies and policies that revealed the necessity to have talent management. Since the study survey was distributed to all workers at the intended hospitals regardless of their positions, this study helps medical and managerial employees, supervisors and managers to construct a deeper perspective and a better understanding of what is really needed to have masterful talents.

Furthermore, for hospitals to acquire a competitive advantage in the susceptible business domain at the local health care private service sector, they have a wide area for exploitation and improvement for their significant human resource asset. This justifies the shift from applying the classic human resource processes and activities into acquiring and developing human resource strategies and policies that emphasized the necessity to have talent management. Since the study survey was distributed to all workers at the intended hospitals regardless of their positions, this study can help medical and managerial employees, supervisors and managers to obtain a deeper perspective and a better understanding of what is really needed to have master talents.

The resulted findings of this study indicate that attracting talents have a positive relationship with the organizational effectiveness with a value equals to (0.439), and this relationship is significant at level $(0.01)$. Moreover, the multiple regression analysis results found that attract talent have a significant effect on organizational effectiveness with a value of (0.129). This study findings are consistent with the findings of Fapohunda (2014), who believes that in order to boost the organizational overall performance and thus to enhance its effectiveness, the organization management must be committed to identifying and obtaining a promising manpower, that is through designing compatible plans.

The study outcomes indicate that maintain talent has as well a positive relationship with organizational effectiveness with a value equals to (0.482), and this relationship is significant at level (0.01). The multiple regression analysis results also indicated that maintaining talents has a significant effect on organizational effectiveness with a value of (0.120). The provided result is in line with results of researchers (Abadi et al., 2013) and (Revis, 2008), where Abadi and his colleagues believed that in order to cover all the related factors impacting an organization by talent departure and demission; an organization should be equipped with a key strategic plan to maintain job stability and security. Revis (2008) concluded that there is a positive relationship between talent retention and organizational effectiveness in terms of competitiveness and growth.

Another indication of these study results that developing talent has a positive relationship with organizational effectiveness with a value of $(0.475)$ and this relationship is significant at level (0.01). In this regard, the multiple regression analysis results found that maintaining talent has as well a significant effect on organizational effectiveness with a value of (0.129).This result comes with accordance with the results found by researchers (Nobarieidishe et al., 2014) and (Collings and Mellahi, 2009), whereas Nobarieidishe and his colleagues considered talent development and training one of the three crucial dimensions that shape talent management. They indicate that develop talent directly influences the employee's productivity and growth, thus leading to create a competitive advantage for the organization by its committed human asset. Moreover, Collings and Mellahi concluded that talent pool development has the highest impact on organizational effectiveness in terms of giving the organization a competitive advantage and a prospective status. The study results indicate that all of the talent management three dimensions are highly significant, and all of them show a positive effect on the 
organizational effectiveness.

\subsection{Study Practical Contribution}

This paper is a literature-based study, whereas each previously conducted research has been applied within various conditions, scopes and circumstances. While this study conducted in a Middle Eastern country, Jordan, most of the reviewed studies were applied in other countries, such as the U.S, some of the Europe countries, Turkey, Pakistan, Iran, and South Korea. These has been also applied on different economic and service sectors, such as national banks, factories, petroleum, governmental health sector and so many. Moreover, researcheswho measured the effect of the intended variable haven't cover -as it should- the current gap due to examining the direct effect of talent management on organizational effectiveness in specific. Nevertheless, the findings of this study confirm prior studies' findings in underlining the reliance on organization's managers to pay more attention and be fully committed to applying talent management. The results clearly show that the hospital management has to design talent-oriented strategies and policies, and apply it sequentially among all their departments and units employees, for the sake of attracting, maintaining, and developing talents.

In light of this, hospitals will likely need to acclimate and activate their talent management strategies to assist shifting business requirements and make extra efforts in order to sustain their valuable employees from other competitors. In addition, it is agreed that there is a positive and high effect of talent management on organizational effectiveness. However, there is a limited interest in the application of talent management notions locally, and over the Jordanian private health care sector in particular, thus the researchers hope throughout this study to decrease the gap related to the targeted study's population.

\subsection{The Study Limitations and Recommendations}

Conducting a research in normally faced with obstacles and limitation throughout the research duration in which suggested recommendations are presented to guide future research. The first limitation encountered through this study that the main focus was mainly over five private hospitals in Jordan; while future researches are recommended to cover more hospitals at the private as well as the governmental health care sector hospitals. This shall help them produce more generalizable outcomes, as they will be adopting other sampling types unlike the convenience sample used by the researchers in this study. Another limitation is that the sampled size didn't reach the statistically estimated sample size amount regarding the chosen population volume. So that for future studies it is better to consider a higher sample size to make the outcomes more valid and more reliable. Moreover, talent management was examined in this study through using a model adopted from a published study by (Nobarieidishe et al., 2014), which included attract talent, maintain talent, and develop talent, as well as organizational effectiveness, and was split into two dimension; job satisfaction and organizational involvement. For future studies, it is recommended to employ other suggested models. Furthermore, since this study was towards examining the direct effect of the independent variable, talent management, on organizational effectiveness; which represented the dependent variable. It is recommended for future work to add mediating variables as well, in order to explain the variance in the dependable variable.

Also, researchers called for more research on the enabling factors of applying electronic services (e.g. Masa'deh, et al., 2008, 2013a, 2013b; Karajeh \& Maqableh, 2014; Maqableh \& Karajeh, 2014; Al-Dmour et al., 2015; Almajali \& Maqableh, 2015; Kateb et al., 2015; Maqableh et al., 2015; Masa'deh, 2016; Tarhini et al., 2015; 2016, 2017a, 2017b; Almajali \& Al-Dmour, 2016; Almajali et al., 2016; Alenezi et al., 2017; Aldmour et al., 2017; Khwaldeh et al., 2017; Mikkawi \&Al-Lozi, 2017; Obeidat et al., 2017; Yassien \& Mufleh, 2017; Tarhini et al., 2018; Al-Dmour et al., 2019), hence, the researchers highly recommend conducting more researches on the Arab region, and specifically in Jordan on the healthcare sector, due to the lack of studies that engaged the healthcare domain from a managerial aspect perspective.

\section{References}

Abualoush, S. H., Obeidat, A. M., Tarhini, A., Masa'deh, R., \& Al-Badi, A. (2018b). The role of employees' empowerment as an intermediary variable between knowledge management and information systems on employees' performance. VINE Journal of Information and Knowledge Management Systems, 48(2), 217-237.

Abualoush, S., Bataineh, K., \& Alrowwad, A. (2018a). The role of knowledge management process and intellectual capital as intermediary variables between knowledge management infrastructure and organization performance. Interdisciplinary Journal of Information, Knowledge, and Management, 13, 279-309.

Al Azmi, N., Al-Lozi, M., Al-Zu'bi, Z., \& Dahiyat, S. (2012). Patients attitudes toward service quality and its 
impact on their satisfaction in physical therapy in KSA hospitals. European Journal of Social Sciences, 34(2), 300-314.

Al-dalahmeh, M., Khalaf, R., \& Obeidat, B. (2018). The effect of employee engagement on organizational performance via the mediating role of job satisfaction: The case of IT employees in Jordanian banking sector. Modern Applied Science, 12(6), 17-43.

Al-Dmour, R, Obeidat, B., \& Almajali, D. (2015). The practice of HRIS applications in business organizations in Jordan: An empirical study. 4th Scientific \& Research Conference on New Trends in Business, Management and Social Sciences (COES\&RJ-TK15/1).

Al-Dmour, R., Al Haj Dawood, E., Al-Dmour, H., \& Masa'deh, R. (2019). The effect of customer lifestyle patterns on the use of mobile banking applications in Jordan. Int. J. Electronic Marketing and Retailing, Forthcoming.

Aldmour, R., Masa'deh, R., \& Obeidat, B. (2017). Factors influencing the adoption and implementation of HRIS applications: Are they similar. International Journal of Business Innovation and Research, 14(2), 139-167.

Alenezi, H., Tarhini, A., Alalwan, A., \& Al-Qirim, N. (2017). Factors affecting the adoption of e-government in Kuwait: A qualitative study. Electronic Journal of e-Government, 15(2), 84-102.

AlHarrasi, J., \& AL-Lozi, M. (2015). The role of innovation management and technological innovation on organizational effectiveness. 4th Scientific \& Research Conference on New Trends in Business, Management and Social Sciences (COES\&RJ-TK15/1), Istanbul, Turkey.

AlHrassi, J., Al-Lozi, M., \& Irtaimeh, H. (2016). The impact of management innovation and technological innovation on organizational effectiveness: An empirical study from managerial staff perspective in Sultan Qaboos University. Journal of Social Sciences (COES\&RJ-JSS), 5(3), 309-339.

Alkandari, A., Masa'deh, R., \& Al-Lozi, M. (2017). Knowledge management and its role on organizational crisis management: A literature review. Journal of Social Sciences (COES\&RJ-JSS), 6(4), 833-850.

Allen, N., \& Meyer, J. (1990). The measurement and antecedents of affective, continuance, and normative commitment to the organization. The Journal of Occupational Psychology, 63, 1-18.

Almajali, D., \& Al-Dmour, R. (2016). The role of information technology in motivating students to accept e-learning adoption in universities: A case study in Jordanian universities. Journal of Business \& Management (COES\&RJ-JBM), 4(1), 36-46.

Almajali, D., \& Maqableh, M. (2015). Assessing the digital divide status of the Jordanian telecentre. International Journal of Communications, Network and System Sciences, 8(11), 428-439.

Almajali, D., Masa'deh, R., \& Al-Lozi, M. (2016). Determinants of the actual use of e-learning systems: An empirical study on Zarqa University in Jordan. Journal of Social Sciences (COES\&RJ-JSS), 5(2), 172-200.

AL-Syaidh, N., Al- Lozi, M., \& AlHarrasi, J. (2016). Transformational leadership and its role on the effectiveness of employees' behavior: A theoretical study. Journal of Business \& Management (COES\&RJ-JBM), 4(1), 14-35.

Amah, E., \& Ahiauzu, A. (2013). Employee involvement and organizational effectiveness. Journal of Management Development, 32(7), 661-674.

An, J., Yom, Y., \& Ruggiero, J. (2011). Organizational culture, quality of work life, and organizational effectiveness in Korean university hospitals. Journal of Transcultural Nursing, 22(1), 22-30.

Collings, D.G., \& Mellahi, K. (2009). Strategic talent management: A review and research agenda. Human Resource Management Review, 19(4), 304-313.

Darawsheh, S., ALshaar, A., \& AL-Lozi, M. (2016). The degree of heads of departments at the University of Dammam to practice transformational leadership style from the point of view of the faculty members. Journal of Social Sciences (COES\&RJ-JSS), 5(1), 56-79.

Drost, E. A. (2011). Validity and reliability in social science research. Education Research and Perspectives, 38(1), 105-123.

El-Tohamy, A., \& Al Raoush, A. (2015). The impact of applying total quality management principles on the overall hospital effectiveness: An empirical study on the HCAC accredited governmental hospitals in Jordan. European Scientific Journal, 11(10), 63-76.

Fapohunda, T. (2014). Increasing organizational effectiveness through better talent management. Research 
Journal of Human Resource, 2(4).

Hair, J., Black, W., Babin, B., Anderson, R., \& Tatham, R. (2010). Multivariate data analysis. (7th edition), New Jersey: Prentice-Hall.

Karajeh, H., \& Maqableh, M. (2014). Security of cloud computing environment. The 23rd IBIMA Conference on Vision 2020: Sustainable Growth, Economic Development, and Global Competitiveness, USA, 2202-2215.

Kateb, M., Swies, R., Obeidat, B., \& Maqableh, M. (2015). An investigation on the critical factors of information system implementation in Jordanian information technology companies. European Journal of Business and Management, 7(36), 11-28.

Khalayleh, W., Masa'deh, R., \& Al-Lozi, M. (2017). Administrative empowerment and its role on the work teams Performance: A literature review. Journal of Social Sciences (COES\&RJ-JSS), 6(4), 851-868.

Khwaldeh, S., Al-Hadid, I., Masa'deh, R., \& Alrowwad, A. (2017). The association between e-services web portals information quality and ICT competence in the Jordanian universities. Asian Social Science, 13(3), 156-169.

Maqableh, M., \& Karajeh, H. (2014). Job scheduling for cloud computing using neural networks. Communications and Network, 6(3), 191-200.

Maqableh, M., Rajab, L., Quteshat, W., Khatib, T., \& Karajeh, H. (2015). The impact of social media networks websites usage on students' academic performance. Communications and Network, 7(4), 159-171.

Masa'deh, R. (2016). The role of knowledge management infrastructure in enhancing job satisfaction at Aqaba five star hotels in Jordan. Communications and Network, 8(4), 219-240.

Masa'deh, R., Alrowwad, A., Alkhalafat, F., Obeidat, O., \& Abualoush, S. (2018). The role of corporate social responsibility in enhancing firm performance from the perspective of IT employees in Jordanian banking sector: The mediating effect of transformational leadership. Modern Applied Science, 12(7), 1-26.

Masa'deh, R., Gharaibeh, A., Maqableh, M., \& Karajeh, H. (2013a). An empirical study of antecedents and outcomes of knowledge sharing capability in Jordanian telecommunication firms: A structural equation modeling approach. Life Science Journal, 10(4), 2284-2296.

Masa'deh, R., Hunaiti, Z., \& Bani Yaseen, A. (2008). An integrative model linking IT-business strategic alignment and firm performance: The mediating role of pursuing innovation and knowledge management strategies. Communications of the International Business Information Management Association (IBIMA) Journal.

Masa'deh, R., Obeidat, B., Zyod, D., \& Gharaibeh, A. (2015). The associations among transformational leadership, transactional leadership, knowledge sharing, job performance, and firm performance: A theoretical model. Journal of Social Sciences (COES\&RJ-JSS), 4(2), 848-866.

Masa'deh, R., Shannak, R., \& Maqableh, M. (2013b). A structural equation modeling approach for determining antecedents and outcomes of students' attitude toward mobile commerce adoption. Life Science Journal, 10(4), 2321-2333.

Messick, S. (1998). Test validity: A matter of consequence. Social Indicators Research, 45(1-3), 35-44.

Mikkawi, B., \& Al-Lozi, M. (2017). The impact of knowledge management infrastructure on academic staff effectiveness: An empirical study at The University of Jordan. Jordan Journal of Business Administration, 13(1), 95-127.

Ministry of Health Annual Report (2013). Ministry of health official. Retrieved from http://www.moh.gov.jo

Nobarieidishe, S., Chamanifard, R., \& Nikpour, A. (2014). The relationship between talent management and organizational commitment in international division of Tejarat bank, Iran. European Online Journal of Natural and Social Sciences, 3(4), 1116-1123.

Obeidat, B., Hadidi, A., \& Tarhini, A. (2017). Factors affecting strategy implementation: A case study of pharmaceutical companies in the Middle East. Review of International Business and Strategy, 27(3), 386-408.

Obeidat, B., Tarhini, A., \& Aqqad, N. (2017). The impact of intellectual capital on innovation via the mediating role of knowledge management: A structural equation modeling approach. International Journal of Knowledge Management Studies, 8(3/4), 273-298.

Oppenheim, A. (1992). Questionnaire design, interviewing and attitude measurement. London: Continuum. Part 
II. Annals of Internet Medicine, 125(11), 917-928.

Pallant, J. (2005). SPSS survival manual: A step guide to data analysis Using SPSS for windows version, 12. Chicago, Illinois: Open University Press.

Revis, B. (2008). Talent management in hospitality: Graduate career success and strategies. International Journal of Contemporary Hospitality Management, 20(7), 781-791.

Schuler, R., Jackson S., \& Tarique, I. (2011). Global talent management and global talent challenges: Strategic opportunities for IHRM. Journal of World Business, 46, 506-516.

Sekaran, U., \& Bougie, R. (2012). Research methods for business (5th ed). United Kingdom: John Wiley \& Sons Ltd.

Suifan, T., Abdallah, A., \& Sweis, R. (2015). The effect of a manager's emotional intelligence on employees "work outcomes in the insurance industry in Jordan". International Business Research, 8(9), 67-82.

Tarhini, A., Alalwan, A., Al-Qirim, N., \& Algharabat, R. (2018). An analysis of the factors influencing the adoption of online shopping. International Journal of Technology Diffusion (IJTD), 9(3), 68-87.

Tarhini, A., Al-Badi, A., Almajali, M., \& Alrabayaah, S. (2017a). Factors influencing employees' intention to use cloud computing. Journal of Management and Strategy, 8(2), 47.

Tarhini, A., Al-Busaidi, K., Bany Mohammed, A., \& Maqableh, M. (2017b). Factors influencing students' adoption of e-learning: A structural equation modeling approach. Journal of International Education in Business, 10(2), 164-182.

Tarhini, A., Bany Mohammed, A., \& Maqableh, M. (2016). Modeling factors affecting student's usage behaviour of e-learning systems in Lebanon. International Journal of Business and Management, 11(2), 299.

Tarhini, A., Mgbemena, C., \& Trab, M. S. A. (2015). User adoption of online banking in Nigeria: A qualitative study. Journal of Internet Banking and Commerce, 20(3), 1-8.

Yassien, E., \& Mufleh, M. (2017). The impact of ERP system's usability on enterprise resource planning project implementation success via the mediating role of user satisfaction. Journal of Management Research, 9(3), 49-71.

\section{Copyrights}

Copyright for this article is retained by the author(s), with first publication rights granted to the journal.

This is an open-access article distributed under the terms and conditions of the Creative Commons Attribution license (http://creativecommons.org/licenses/by/4.0/). 